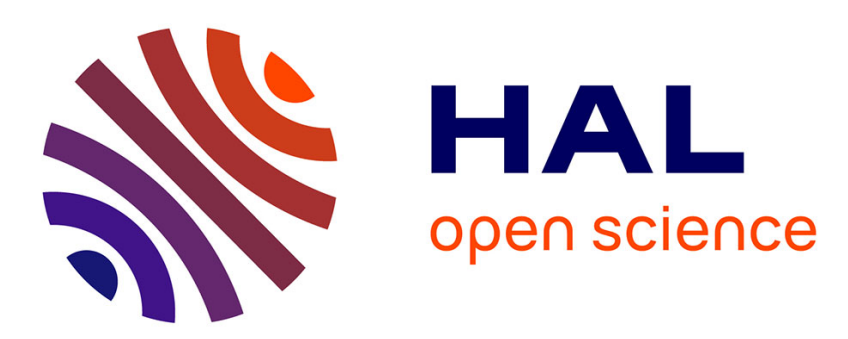

\title{
Genetic study of some agronomic characters in winter oilseed rape (Brassica napus L.) II. - Genetic parameters
}

Marianne Lefort-Buson, Yvette Dattée, Olivier Lavoisier

\section{To cite this version:}

Marianne Lefort-Buson, Yvette Dattée, Olivier Lavoisier. Genetic study of some agronomic characters in winter oilseed rape (Brassica napus L.) II. - Genetic parameters. Agronomie, 1982, 2 (4), pp.323-332. hal-00884388

\section{HAL Id: hal-00884388 \\ https://hal.science/hal-00884388}

Submitted on 1 Jan 1982

HAL is a multi-disciplinary open access archive for the deposit and dissemination of scientific research documents, whether they are published or not. The documents may come from teaching and research institutions in France or abroad, or from public or private research centers.
L'archive ouverte pluridisciplinaire HAL, est destinée au dépôt et à la diffusion de documents scientifiques de niveau recherche, publiés ou non, émanant des établissements d'enseignement et de recherche français ou étrangers, des laboratoires publics ou privés. 


\title{
Genetic study of some agronomic characters in winter oilseed rape (Brassica napus L.) II. - Genetic parameters
}

\author{
Marianne LEFORT-BUSON \& Yvette DATTÉE (*) \\ with the collaboration of Olivier LAVOISIER \\ I.N.R.A., Station d'Amélioration des Plantes, Centre de Recherches agronomiques de Rennes, B.P. 29, \\ F 35650 Le Rheu. \\ (*) Université Paris XI, Laboratoire de Biologie végétale, Bâtiment 362, F 91405 Orsay Cedex.
}

\section{SUMMARY \\ Rapeseed, \\ Brassica napus, \\ Genetic parameters, \\ General combining \\ ability, \\ Specific combining \\ ability, \\ Reciprocal effects, \\ Seed yield, \\ Agronomic characters, \\ Genetic correlations.}

From the available winter rape inbred line population, 25 lines were crossed according to an incomplete diallel design; general and specific combining ability effects (G.C.A., S.C.A.), general and specific reciprocal effects (M.R.E., S.R.E.), as well as their relative variances were evaluated for several traits.

Variability of all these characters except height and density appeared to be mainly additive; the variance of reciprocal effects which was found to occur was much lower than the G.C.A. variance. In contrast, height and density displayed great specific effects. Consequently, it is suggested that $F_{1}$ hybrids should be selected on the basis of their G.C.A. estimates, especially since these estimates appeared to be linked to the values for inbred line.

The simultaneous occurrence of additivity in crossing and of heterosis in a partially autogamous species such as rape is discussed relative to similar phenomena in allogamous species.

\author{
RÉSUMÉ \\ Colza, \\ Brassica napus, \\ Paramètres génétiques, \\ Aptitude générale à la \\ combinaison, \\ Aptitude spécifique à la \\ combinaison, \\ Effets réciproques, \\ Rendement en grain, \\ Caractères agrono- \\ miques, \\ Corrélations génétiques.
}

Etude génétique de quelques caractères agronomiques chez le colza oléagineux d'hiver (Brassica napus L.). II. - Paramètres génétiques

L'article s'intéresse aux paramètres génétiques d'une population de lignées sélectionnées en vue d'optimiser la sélection d'hybrides $F_{1}$ de colza. Vingt-cinq géniteurs ont été tirés de la population et croisés selon un plan diallèle incomplet pour estimer les variances relatives des effets d'aptitude à la combinaison générale (A.G.C.) et spécifique (A.S.C.) ainsi que celles des effets réciproques moyens (E.R.M.) et spécifiques (E.R.S.).

Les effets d'A.G.C. créent la majeure partie de la variation pour tous les caractères étudiés (caractères de productivité et caractères végétatifs) à l'exception de la hauteur des plantes et du peuplement où les effets spécifiques semblent importants. Pour certains caractères (hauteur, précocité de floraison, sensibilité à la verse), des effets réciproques ont été mis en évidence mais leur variance est faible comparée à celle des A.G.C.

Sous réserve de confirmation ultérieure de ces résultats, il est suggéré de sélectionner les hybrides $F_{1}$ sur la base de la valeur en A.G.C. des lignées parentales pour obtenir un meilleur gain génétique ; de plus, la valeur en A.G.C. est liée positivement à la valeur en lignée au sein de la population considérée.

La coexistence d'un effet d'hétérosis et d'une forte variance d'A.G.C., phénomène que l'on retrouve chez plusieurs espèces allogames, est longuement discutée dans le cas du colza, espèce semi-allogame. Chez les espèces autogames ou semi-allogames pour lesquelles l'autofécondation fait partie du système naturel de reproduction, la variabilité génétique a sûrement la même origine chez les lignées et les hybrides ; l'hétérosis, dû en grande partie à une accumulation de gènes majeurs, pourrait être fixé au cours du temps. Par contre, chez les cspèces allogames où les phénomènes d'hétérosis sont souvent très importants, la variabilité génétique révélée en croisement et en autofécondation n'aurait pas la même nature chez les lignées et les hybrides; l'expression de gènes majeurs chez les hétérozygotes serait liée à l'existence d'une bonne balance de relation. Ainsi l'hétérosis serait beaucoup moins facilement fixé chez les allogames que chez les autogames.

\section{INTRODUCTION}

Considerable heterosis effects for seed yield and other characters of winter rapeseed lead to the breeding of hybrid varieties.
Gencrally, the efficiency of a breeding method comes from the full use of variability, statistically expressed as the variance of a quantitative character.

For hybrids the total variance is classically divided into variances of general (G.C.A.) and specific (S.C.A.) combi- 
ning abilities and into variances of general (M.R.E.) and specific (S.R.E.) reciprocal effects. Roughly, paired comparisons of these variances give information about the selection scheme:

i) when G.C.A. variance is higher than S.C.A. variance, individuals would be selected since G.C.A. is a gamete feature ;

ii) when S.C.A. variance is higher, many couples have to be tested in order to choose the best ones, since S.C.A. is a zygotic feature ;

iii) the relative importance of M.R.E. and S.R.E. variances compared with G.C.A. and S.C.A. variances allows us to evaluate the interest of reciprocal crosses.

This paper deals with the genetic parameters of a selected population of winter rape lines in order to improve the selection of $F_{1}$ hybrids. Relations between the values of inbred lines and G.C.A. effects as well as correlations between the G.C.A. effects of all the characters were calculated whenever possible.

\section{MATERIALS AND METHODS}

\section{A. Experimental design}

An incomplete diallel design, made of many small and complete diallels, was used to get a measure of reciprocal effects and to obtain a good accuracy of G.C.A. variances.

The size ( $n$ ) and the number ( $r$ ) of the small diallels were chosen so that the relative accuracy of any parameter estimate was about the same with the hybrid number being limited to 140 , r.n. $(n-1)=140$.

Equations of relative accuracies of variances were developed by LEFORT (1977) and are given in table 1 ; these accuracies are expressed in terms of ratios of unknown parameters $(\gamma \mathrm{g}, \gamma \mathrm{s}, \gamma \mathrm{m}, \gamma \mathrm{r})$ to $\gamma \mathrm{e}$. Accuracies of the direct effect estimates $(\gamma \mathrm{s}, \gamma \mathrm{g})$ were evaluated in different designs and are compared in table 2 ; accuracies were identical in the case of reciprocal effects and we did not report them. Except when $\gamma g=\gamma \mathrm{s}$, accuracy of S.C.A. variances was slightly higher in a $(7,3)$ design and the accuracy of G.C.A.

TABLE 1

Estimates of relative accuracies of the variances of different effects in complete or incomplete diallel designs (from LEFORT, 1977). Précisions relatives des variances des différents effets pour des dispositifs diallèles complets ou incomplets (d'après LEFORT, 1977).

Type of

\begin{tabular}{|c|c|c|}
\hline G.C.A. & $\Pi_{\mathrm{g}}=\frac{\operatorname{var} \gamma_{\mathrm{g}}}{\gamma_{\mathrm{g}} 2}=\frac{2}{v_{\mathrm{i}}}\left[\left(1+\frac{\gamma_{\mathrm{s}}+\gamma_{\mathrm{e}} / 2 \mathrm{~b}}{(\mathrm{n}-2) \gamma_{\mathrm{g}}}\right)^{2}+\frac{2(\mathrm{n}-1)}{\mathrm{n}(\mathrm{n}-3)}\left(\frac{\gamma_{\mathrm{s}}+\gamma_{\mathrm{e}} / 2 \mathrm{~b}}{(\mathrm{n}-2) \gamma_{\mathrm{g}}}\right)^{2}\right]$ & $r(n-1)$ \\
\hline S.C.A. & $\Pi_{\mathrm{s}}=\frac{\operatorname{var} \gamma_{\mathrm{s}}}{\gamma_{\mathrm{s}} 2}=\frac{2}{v_{\mathrm{i}}}\left[\left(1+\frac{\gamma_{\mathrm{e}}}{2 \mathrm{~b} \gamma_{\mathrm{s}}}\right)^{2}+\frac{(\mathrm{n}-3)}{2(\mathrm{n}-1)(\mathrm{b}-1)}\left(\frac{\gamma_{\mathrm{e}}}{2 \mathrm{~b} \gamma_{\mathrm{s}}}\right)^{2}\right]$ & $m(n-3)$ \\
\hline M.R.E. & $\Pi_{m}=\frac{\operatorname{var} \gamma_{m}}{\gamma_{m} 2}=\frac{2}{v_{i}}\left[1+\left(\frac{\gamma_{r}+\gamma_{e} / 2 b}{n \gamma_{m}}\right)^{2}+\frac{2}{(n-2)}\left(\frac{\gamma_{r}+\gamma_{e} / 2 b}{n \gamma_{m}}\right)^{2}\right]$ & $r(n-1)$ \\
\hline S.R.E. & $\Pi_{\mathrm{r}}=\frac{\operatorname{var} \gamma_{\mathrm{r}}}{\gamma_{\mathrm{r}} 2}=\frac{2}{v_{\mathrm{i}}}\left[\left(1+\frac{\gamma_{\mathrm{e}} / 2 \mathrm{~b}}{2 \mathrm{~b} \gamma_{\mathrm{r}}}\right)^{2}+\frac{(\mathrm{n}-2)}{2 \mathrm{n}(\mathrm{b}-1)}\left(\frac{\gamma_{\mathrm{t}}}{2 \mathrm{~b} \gamma_{\mathrm{r}}}\right)^{2}\right]$ & $\frac{r(n-1)(n-2)}{2}$ \\
\hline
\end{tabular}

( $r$ is the number of unit diallel designs; $n$ is the number of inbreds in each diallel design, $b$ is the repetition number, $\gamma s, \gamma r, \gamma g, \gamma m$ and $\gamma e$ are the variances of respectively S.C.A., S.R.E., G.C.A., M.R.E. and residual effects).

( $\mathrm{r}$ est le nombre de diallèles élémentaires ; $n$ est le nombre de lignées dans chaque dispositif élémentaire, b est le nombre de répétitions, $\gamma s, \gamma r$, $\gamma \mathrm{g}, \gamma \mathrm{m}$ et $\gamma \mathrm{e}$ sont les variances des effets respectivement d'A.S.C., d'E.R.S., d'A.G.C., d'E.R.M. et résiduels).

TABLE 2

Relative accuracies of G.C.A. and S.C.A. effects for different 3-replication designs.

Précisions relatives des variances d'A.G.C. et d'A.S.C. pour quelques valeurs des rapports $\gamma_{s} / \gamma_{e}$ et $\gamma_{g} / \gamma_{e}$ dans des dispositifs à 3 répétitions.

\begin{tabular}{|c|c|c|c|c|c|c|c|}
\hline \multirow[b]{2}{*}{$(\mathrm{n}, \mathrm{r})$} & \multirow[b]{2}{*}{$\operatorname{rn}(n-1)$} & \multicolumn{2}{|c|}{$\frac{\gamma_{s}}{\gamma_{c}}=\frac{\gamma_{g}}{\gamma_{e}}=\frac{1}{6}$} & \multicolumn{2}{|c|}{$\frac{\gamma_{\mathrm{s}}}{\gamma_{\mathrm{e}}}=\frac{1}{8} ; \frac{\gamma_{\mathrm{g}}}{\gamma_{\mathrm{e}}}=\frac{1}{4}$} & \multicolumn{2}{|c|}{$\frac{\gamma_{s}}{\gamma_{e}}=\frac{1}{12} ; \frac{\gamma_{s}}{\gamma_{e}}=\frac{1}{3}$} \\
\hline & & $\left(\pi_{\mathrm{s}}\right)^{1 / 2}$ & $\left(\pi_{g}\right)^{1 / 2}$ & $\left(\pi_{s}\right)^{1 / 2}$ & $\left(\pi_{\mathrm{g}}\right)^{1 / 2}$ & $\left(\pi_{\mathrm{s}}\right)^{1 / 2}$ & $\left(\pi_{g}\right)^{1 / 2}$ \\
\hline$(4,11)$ & 132 & 0,609 & 0,577 & 0,712 & 0,428 & 0,920 & 0,356 \\
\hline$(5,7)$ & 140 & 0,486 & 0,573 & 0,569 & 0,382 & 0,736 & 0,339 \\
\hline$(6,4)$ & 120 & 0,481 & 0,486 & 0,563 & 0,415 & 0,730 & 0,378 \\
\hline$(7,3)$ & 126 & 0,445 & 0,474 & 0,522 & 0,415 & 0,678 & 0,385 \\
\hline
\end{tabular}


variances was a little better in a $(5,7)$ design. Since the G.C.A. variance is usually higher than the S.C.A. variance for most of the species, the last design was chosen.

It was assumed that the winter rape collection at the Plant Breeding Station of Rennes was representative of the population of winter rape selected lines. 21 inbred lines were sampled and divided three-by-three into each small diallel. Two inbred lines without erucic acid ( $\mathrm{R} 39$ », «Primor») or (« Rafal», «Primor ») were added to each small diallel in order to increase the probabilities of getting good combinations to be used immediately for selection; further, the presence of «Primor» in each small diallel makes their comparison easier.

Any small diallel was composed of inbred lines with the lowest kinship coefficient ; results of each diallel were then independent and the statistical analysis was easier. We assumed that each kinship coefficient within each small diallel was equal to 0 ; but such an assumption is wrong when the whole diallel is concerned.

A 2-replication randomized block design was used for the experiment ; the two replications of one diallel were pooled. Plots were composed or 4 rows ( $3 \mathrm{~m}$ length, $0,30 \mathrm{~m}$ between rows). Reciprocal hybrids were divided into smaller blocks in order to reduce the block size; consequently, only S.R.E. accuracy was decreased.

Some agronomic characters were measured on the 2 inner lines of each plot (density at maturity, flowering date, leaf canopy at beginning of flowering, lodging susceptibility, seed yield); other characters such as height, and number of leaves at rosette stage, stem base diameter and height at beginning of flowering, height, branching number and yield components at maturity, were measured on 4 plants remote enough to prevent any correlations between the measures ; (logarithms were used for allometric characters such as length and neck diameter).

\section{B. Methods of investigation}

The phenotypic value of a cross $(i, j)$ between a female plant $\mathrm{i}$ and a male plant $\mathrm{j}$, is currently subdivided into :

$$
Y_{i j k}=\mu+g_{i}+g_{j}+m_{i}-m_{j}+s_{i j}+r_{i j}+E_{i j k}
$$

where $g_{i}$ and $g_{j}$ are the G.C.A. of plants $i$ and $j$ respectively; the genetic variance is $\sigma^{2} \mathrm{~g}$;

$\mathrm{m}_{\mathrm{i}}$ and $\mathrm{m}_{\mathrm{j}}$ are the M.R.E. of plants $\mathrm{i}$ and $\mathrm{j}$ respectively ; the variance is $\sigma^{2} \mathrm{~m}$;

$s_{i j}$ and $r_{i j}$ are the S.C.A. and S.R.E. of parental couple $(i, j)$; variances are $\sigma^{2} s$ and $\sigma^{2} r$ respectively; $\left(s_{i j}=s_{j i}\right.$, $\left.r_{i j}=-r_{j i}\right)$;

$E_{i j k}$ is the residual variable.

From the correspondence between this statistical equation and the genetic expression of the phenotypic value, $\mathrm{P}=\mathrm{M}+\mathrm{A}+\mathrm{D}+\mathrm{I}+\mathrm{E}$ (where $\mathrm{A}, \mathrm{D}, \mathrm{I}, \mathrm{E}$ are the additive effects, the dominance effects, the epistasis effects and the residual effects respectively), an expression of heritability sensu-stricto may be derived assuming that parents are not related, that $\mathrm{g}$ and $\mathrm{m}$ are not correlated and that there is no epistasis :

$$
\mathrm{h}^{2}=2 \frac{\sigma^{2} \mathrm{~g}+\sigma^{2} \mathrm{~m}}{\sigma^{2} \mathrm{P}}
$$

The two last assumptions are not always confirmed, and this estimate of heritability must be used carefully.

The tabulated equations (table 1) show that the relative accuracies were low, especially as the experiment design comprised only two replications ; therefore, first we assumed that some effects existed, second we roughly estimated variances of those effects which were different from 0 . Besides, the computer resources available did not allow us to solve these equations using a random model. So we used models with different effects and chose the best one for each character (see II.B.1) ; the combination of error variances in these models gives an estimate of the mean squares of the different effects (see II.B.2). This cannot be considered as a random model, but we have supposed that the mean squares obtained in such a way could give an estimate of the variances of the effects given in a random model. This assumption will be confirmed later, when the computer will be able to treat random diallel programs.

\section{Choice of a subdivision model}

The occurrence of each effect was tested in a systematic order; several models were defined :

$\mathrm{M}_{0}$, the complete model,

$$
Y_{i j}=\mu+g_{i}+g_{j}+s_{i j}+m_{i}-m_{j}+r_{i j}+E_{i j},
$$

$\mathrm{M}_{1}$, the model without reciprocal effects,

$$
Y_{i j}=M+g_{i}+g_{j}+s_{i j}+m_{i}-m_{j}+E_{i j},
$$

$\mathbf{M}_{2}$, the symmetrical model,

$$
Y_{i j}=\mu+g_{i}+g_{j}+s_{i j}+E_{i j},
$$

$\mathbf{M}_{3}$, the additive model,

$$
Y_{i j}=\mu+g_{i}+g_{j}+m_{i}-m_{j}+E_{i j},
$$

$\mathrm{M}_{4}$, the symmetrical additive model,

$$
Y_{i j}=\mu+g_{i}+g_{j}+E_{i j},
$$

$M_{5}$, the model without genetic effects, $Y_{i j}=\mu+E_{i j}$; in this model we cannot explain variation with any of the four effects $(g, m, s, r)$, but it is possible for the variation to be explained by an effect not defined in the above model.

These models (except $M_{3}$ and $M_{2}$ ) are obviously enclosed in one another, $\left.\left.\mathrm{M}_{0}\right), \mathrm{M}_{1}\right), \mathrm{M}_{2}$ ) and $\mathrm{M}_{3}$ ), $\mathbf{M}_{5}$ ), and the choice of one of them for a specific character was made when testing successively $M_{1}$ to $M_{0}, M_{2}$ and $M_{3}$ to $M_{1}$ (if both tests are significant $\mathbf{M}_{4}$ is chosen), $\mathbf{M}_{5}$ to $\mathbf{M}_{4}$. The model preceding the first one in which the test is significant to a $5 \%$ limit was chosen; a $5 \%$ limit for each test did not too much reduce their power since the total limit was $20 \%$.

\section{Evaluation of genetic variances}

First, each small diallel was analysed and then results were pooled. With one or two exceptions, relationships within a diallel were almost equal to $0:$ it was assumed that the sums of squares had the same characteristics that the classical independent random variables. Assuming that the differences between the errors were due to the differences between the environments, it was further assumed that the genetic variances of all diallels were homogeneous; thus, each sum of squares had the same expectation, and their sum gave a total estimate. Let « Si $»$ be the expected S.C.A. variance within the diallel « $\mathrm{i} »$ :

$$
E\left(S_{i}\right)=\frac{n(n-3)}{2}\left(\gamma_{s}+\frac{\gamma_{e i}}{4}\right)
$$


where $Y_{c}$ is the error for the twice repeated diallel $« i »$; then, the expectation of $\mathrm{S}$, sum of $\mathrm{Si}$, is :

$$
E(S)=n \frac{(n-3)}{2} \sum_{i=1}^{7}\left(\gamma_{s}+\frac{\gamma_{\mathrm{ei}}}{4}\right)=7 \frac{\mathrm{n}(\mathrm{n}-3)}{2}\left(\gamma_{\mathrm{s}}+\frac{\gamma_{\mathrm{e}}}{4}\right) .
$$

Excluding a coefficient, the unbiased expectation of $\gamma_{s}$ is obtained by subtracting the expectation of $\gamma_{\mathrm{s}}$ from $S$. Expectations of $\gamma_{g}, \gamma_{m}, \gamma_{e}$ can be derived in the same way. The accuracy of these estimates could not be precisely calculated because the statistical law of $S$ was not classical due to dependence of the sums of squares; this was due to the relationship between some inbred lines and the repeated use of some others. However a first rough estimate of the accuracy was obtained which overestimates it, using equations given in table 1 . Besides, a confidence interval was also calculated using equations developed for a normal distribution law ; but, because of the lack of accuracy only the upper limit of the interval was taken into account; it is the higher limit value of the parameter under study.

3. Relations between the value of the inbred line and the G.C.A. value; correlations between G.C.A. effects of several characters

In a random model, effects of each parent (G.C.A. and M.R.E.) and of each parental couple (S.C.A., S.R.E.) are estimated by regression; information on all characters is so used to estimate one parent's or combination's effect for one particular character. But in such a model, the calculations are extremely difficult; consequently, effects were finally evaluated assuming a fixed model when the required approximations were not too rough. When the G.C.A. variance is distinctly greater than other genetic variances, the model may be simplified as following: $Y_{i j}=\mu+g_{i}+g_{i}+e_{i j}$.

Assuming a fixed model, estimates of G.C.A. are $\hat{g}_{i}$ : they are not taking into account information about other characters; the range of variation of the $\hat{\mathrm{g}}_{\mathrm{i}}$ values is equal to or greater than the range of variation of the estimates from a random model, but the order is maintained (the design is nearly balanced). When the G.C.A. variance was clearly higher than the others, G.C.A. values of parents and correlations between G.C.A. estimates were calculated; furthermore, regressions of these G.C.A. estimates on the inbred lines values were done. In this case, covariance between G.C.A. and line values must be overestimated; but as G.C.A. variance is also overestimated, it is difficult to know if the correlation coefficient is over or underestimated.

\section{RESULTS}

\section{A. Model chosen for each character}

\section{Vegetative characters (table 3 )}

Using logarithms the symmetrical and complete models were used for height at « rosette » stage and «beginning of flowering " stage respectively. The occurrence of reciprocal effects was thus demonstrated.

Additive genes mainly control the following characters: leaf number at rosette stage, lodging susceptibility, leaf canopy and density at maturity; however mean reciprocal effects (M.R.E.) were significant for the third and fourth characters. The above mentioned models did not explain the large crror of the logarithm of stem base diameter.
TABLE 3

Models chosen for the vegetative characters. Modèles retenus pour les caractères liés au développement végétatif.

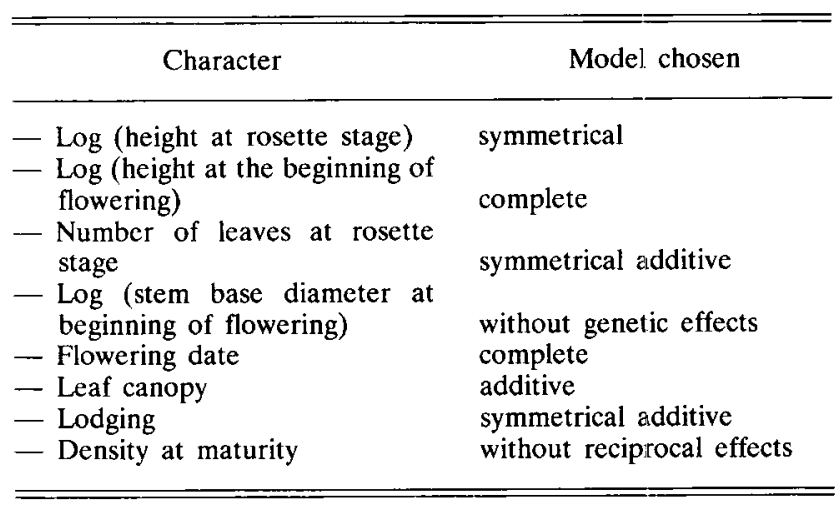

\section{Yield components (table 4)}

Plot seed yield was well predicted by the additive symmetrical model ; the logarithmic transformation caused no further improvement.

For individual plants, the variability of main branch (BI) yield was mainly due to G.C.A. variations, whereas the variability of secondary branch (BII) yield was not well explained by any of the models. The total yield (sum of BI and BII), fitted the model without genetic effects. All yield components (pod number, seed number per pod, 1000 seed weight) fitted an elementary genetic model whether they were estimated on BI or BII : in any case, variability if fully explained by the G.C.A. effects, but we must recall here that sampling was not very good (LEFORT-BUSON, 1982).

\section{B. Evaluations of genetic variances}

\section{Vegetative characters (table 5)}

For logarithms of height at both " rosette » and « beginning of flowering » stages, the variance of specific effects (S.C.A. and S.R.E.) was greater than that of general effects (G.C.A. and M.R.E.) ; the total genetic component was high : 0.40 . Evaluations of heritabilities sensu-stricto were very low $(0.20)$ and about the same for both heights; however the accuracy of these heritability values was low owing to the inaccurate estimates of all variances.

For earliness of flowering, variance of specific effects was much lower than that of genetic effects and heritability was high (0.80).

Although the additive model was not acceptable, variations of leaf canopy and lodging susceptibility were for the most part due to G.C.A. ; heritabilities were intermediate, 0.32 and 0.24 respectively.

Variances of M.R.E. and S.C.A. were involved in genetic variation of density at maturity which display low heritability $(0.13)$.

\section{Yield and yield components (table 6)}

Heritability of plot yield was intermediate $(0.32)$ and equal to those of leaf canopy and lodging resistance. For a spring rape plant, ClARKE $(1977,1978)$ demonstrated that seed yield is determined by leaf area at the beginning of flowering; the above results provide evidence of a similar genetic control for these characters.

Yield and yield components that were appraised on main branches (BI) of individual plants displayed average to high heritabilities $(0.32$ to 0.60$)$. In contrast, the part of additive 
TABLE 4

Models chosen for yield characters.

Modeles retenus pour les caractères de productivité.

\begin{tabular}{|c|c|c|c|}
\hline & & Character & Model chosen \\
\hline Plot & & $\begin{array}{l}\text { - Plot yield } \\
\text { - Log (plot yield) }\end{array}$ & $\begin{array}{l}\text { symmetrical additive } \\
\text { additive }\end{array}$ \\
\hline \multirow{3}{*}{$\begin{array}{c}\text { Individual } \\
\text { Plants }\end{array}$} & $\begin{array}{l}\text { Primary } \\
\text { branches }\end{array}$ & $\begin{array}{l}\text { - Pod number } \\
\text { - Seed number per pod } \\
\text { - } 1000 \text { seed weight } \\
\text { - Yield }\end{array}$ & $\begin{array}{l}\text { symmetrical additive } \\
\text { symmetrical additive } \\
\text { symmetrical additive } \\
\text { symmetrical additive }\end{array}$ \\
\hline & $\begin{array}{l}\text { Secondary } \\
\text { branches }\end{array}$ & $\begin{array}{l}\text { - Pod number } \\
\text { - Seed number per pod } \\
\text { - } 1000 \text { seed weight } \\
\text { - Yield }\end{array}$ & $\begin{array}{l}\text { symmetrical additive } \\
\text { symmetrical additive } \\
\text { symmetrical additive } \\
\text { without genetic effects }\end{array}$ \\
\hline & $\begin{array}{c}\text { All } \\
\text { branches }\end{array}$ & — Total plant yield & without genetic effects \\
\hline
\end{tabular}

TABLE 5

Estimates of variances for vegetative characters.

Variances des effets retenus pour les caractères liés au développement végétatif.

\begin{tabular}{|c|c|c|c|c|}
\hline \multirow{2}{*}{$\begin{array}{c}\text { Character } \\
\begin{array}{c}\text { Log } \\
\text { (height at } \\
\text { rosette stage) }\end{array}\end{array}$} & \multicolumn{2}{|c|}{ Estimates of variances : $\hat{\sigma}^{2}$} & \multirow{2}{*}{$\begin{array}{c}\text { Confidence }\left({ }^{a}\right) \\
\text { Limit for } \hat{\sigma}^{2}\end{array}$} & \multirow{2}{*}{$\begin{array}{c}\hat{\mathrm{h}}^{2}=2 \frac{\sigma_{\mathrm{s}}^{2}}{\sigma_{\mathrm{p}}^{2}} \\
0,23\end{array}$} \\
\hline & $\begin{array}{l}\text { S.R.E. } \\
\text { S.C.A. } \\
\text { G.C.A. } \\
\text { Residual }\end{array}$ & $\begin{array}{r}29 \cdot 10^{-4} \\
57 \cdot 10^{-4} \\
48 \cdot 10^{-4} \\
250 \cdot 10^{-4}\end{array}$ & & \\
\hline $\begin{array}{l}\text { Log } \\
\text { (height at } \\
\text { beginning of } \\
\text { flowering) }\end{array}$ & $\begin{array}{l}\text { S.R.E. } \\
\text { S.C.A. } \\
\text { G.C.A. } \\
\text { Residual }\end{array}$ & $\begin{array}{r}5,6 \cdot 10^{-4} \\
3,7 \cdot 10^{-4} \\
3,9 \cdot 10^{-4} \\
26,0 \cdot 10^{-4}\end{array}$ & $\begin{array}{c}0-238 \cdot 10^{-4} \\
0-270 \cdot 10^{-4} \\
0-218 \cdot 10^{-4} \\
-\end{array}$ & 0,18 \\
\hline $\begin{array}{l}\text { Leaf number at } \\
\text { rosette stage }\end{array}$ & $\begin{array}{l}\text { G.C.A. } \\
\text { Residual }\end{array}$ & $\begin{array}{r}4,8 \cdot 10^{-2} \\
47,3 \cdot 10^{-2}\end{array}$ & ${ }^{0-27,8.10^{-2}}$ & 0,17 \\
\hline $\begin{array}{l}\text { Date of } \\
\text { flowering }\end{array}$ & $\begin{array}{l}\text { S.R.E. } \\
\text { S.C.A. } \\
\text { G.C.A. } \\
\text { Residual }\end{array}$ & $\begin{array}{l}0,148 \\
0,229 \\
3,481 \\
1,406\end{array}$ & $\begin{array}{r}0-0,755 \\
0-0,835 \\
2,428-4,534 \\
-\end{array}$ & 0,80 \\
\hline Leaf canopy & $\begin{array}{l}\text { M.R.E. } \\
\text { G.C.A. } \\
\text { Residual }\end{array}$ & $\begin{array}{l}0,020 \\
0,201 \\
0,956\end{array}$ & $\begin{array}{r}0-0,316 \\
0,056-0,346 \\
-\end{array}$ & 0,32 \\
\hline Lodging & $\begin{array}{l}\text { G.C.A. } \\
\text { Residual }\end{array}$ & $\begin{array}{l}0,234 \\
0,591\end{array}$ & $\begin{array}{l}0-0,557 \\
-\end{array}$ & 0,44 \\
\hline $\begin{array}{l}\text { Density at } \\
\text { maturity }\end{array}$ & $\begin{array}{l}\text { S.C.A. } \\
\text { M.R.E. } \\
\text { G.C.A. } \\
\text { Residual }\end{array}$ & $\begin{array}{r}8,25 \\
7,94 \\
4,24 \\
147,20\end{array}$ & $\begin{array}{r}0,18-8,37 \\
4,82-11,06 \\
0-10,24 \\
-\end{array}$ & 0,13 \\
\hline
\end{tabular}

( $\left.{ }^{a}\right)$ When the lower value of confidence limit was less than 0 , it was given the value 0 .

(a) Lorsque la borne inférieure de l'intervalle de confiance était négative, on lui a donné arbitrairement la valeur 0.

variance involved in the variance of characters measured on BII was much lower; the large error, when components were evaluated on BII, led to acceptance of the model without genetic effects for BII yield and total yield.

\section{Genetic correlations (table 7)}

Correlation between G.C.A. of plot leaf canopy and of plot seed yield was high (0.79). Besides, the more lodging- 
TABLE 6

Estimates of variances for yield characters.

Variances des effets retenus pour les caractères de productivité.

\begin{tabular}{|c|c|c|c|c|}
\hline Character & \multicolumn{2}{|c|}{$\begin{array}{l}\text { Estimates } \\
\text { of variances : } \hat{\sigma}^{2}\end{array}$} & \multirow{2}{*}{$\begin{array}{c}\text { Confidence }\left({ }^{a}\right) \\
\text { limit for } \hat{\sigma}^{2}\end{array}$} & \multirow{2}{*}{$\hat{h}^{2}=\frac{2 \hat{\sigma}_{g}^{2}}{\hat{\sigma}_{\hat{h}}^{2}}$} \\
\hline Plot yield & $\begin{array}{l}\text { G.C.A. } \\
\text { Residual }\end{array}$ & $\begin{array}{c}5,39 \\
25,53\end{array}$ & & \\
\hline $\begin{array}{l}\text { Pod number } \\
\text { for } \mathrm{BI}\end{array}$ & $\begin{array}{l}\text { G.C.A. } \\
\text { Residual }\end{array}$ & $\begin{array}{l}18,93 \\
41,82\end{array}$ & $\begin{array}{c}7,95-29,91 \\
-\end{array}$ & 0,48 \\
\hline $\begin{array}{l}\text { Pod number } \\
\quad \text { for BII }\end{array}$ & $\begin{array}{l}\text { G.C.A. } \\
\text { Residual }\end{array}$ & $\begin{array}{r}295,8 \\
2927,5\end{array}$ & $\begin{array}{c}53,2-538,4 \\
-\end{array}$ & 0,17 \\
\hline $\begin{array}{l}\text { Seed number } \\
\text { per pod on } \\
\text { BI }\end{array}$ & $\begin{array}{l}\text { G.C.A. } \\
\text { Residual }\end{array}$ & $\begin{array}{l}1,807 \\
7,689\end{array}$ & $\begin{array}{c}0,651-2,963 \\
-\end{array}$ & 0,32 \\
\hline $\begin{array}{l}\text { Seed number } \\
\text { per pod on } \\
\text { BII }\end{array}$ & $\begin{array}{l}\text { G.C.A. } \\
\text { Residual }\end{array}$ & $\begin{array}{l}0,483 \\
4,508\end{array}$ & $\begin{array}{l}0-0,99 \\
-\end{array}$ & 0,17 \\
\hline $\begin{array}{c}1000 \text { seed } \\
\text { weight for } \\
\text { BI }\end{array}$ & $\begin{array}{l}\text { G.C.A. } \\
\text { Residual }\end{array}$ & $\begin{array}{l}0,137 \\
0,184\end{array}$ & $\begin{array}{c}0,055-0,220 \\
-\end{array}$ & 0,60 \\
\hline $\begin{array}{l}1000 \text { seed } \\
\text { weight for } \\
\text { BII }\end{array}$ & $\begin{array}{l}\text { G.C.A. } \\
\text { Residual }\end{array}$ & $\begin{array}{l}0,147 \\
1,442\end{array}$ & $0-0,302$ & 0,17 \\
\hline Yield of BI & $\begin{array}{l}\text { G.C.A. } \\
\text { Residual }\end{array}$ & $\begin{array}{l}0,262 \\
0,404\end{array}$ & $\begin{array}{c}0,102-0,421 \\
-\end{array}$ & 0,57 \\
\hline
\end{tabular}

(a) When the lower value of confidence limit was less than 0 , it was given the value 0 .

(a) Lorsque la borne inférieure de l'intervalle de confiance était négative, on lui a donné arbitrairement la valeur 0 .

resistant the hybrids were, the more abundant was the leaf development at the beginning of flowering and the higher was the yield; but, evaluations of these correlations were low (about 0.40).

Genetic correlations between G.C.A. of plant pod number ( $x$ ) and of plant seed yield (z), or between G.C.A. of plant seed number by pod (y) and of plant seed yield ( $\mathrm{z}$ ), were significant when evaluated on the main branching $\mathrm{BI}$; variables $x$ and $y$ were not related, which resulted in a high value of the correlation between the couple ( $x y)$ and $z$ $(\hat{\rho}=0.902)$.

On the main branches (BI), the 1000 seed weight was not compensating for yield, although such a compensatory effect was demonstrated at a phenotypic level when the whole plant was concerned (BUSON, 1979).

In contrast, for BII, pod number and seed number per $\operatorname{pod}(y)$ were strongly correlated $(\hat{\rho}=0.535)$.

Very few correlations between characters measured on the average of 4 plants on the one hand and roughly in the plot on the other were significant. A correlation estimate between BI yield and plot yield was not significant; there are two ways of explaining this : the real lack of relationship between the two yields and the inability of the 4-plant sample to represent the plot satisfactorily.

For any of the characters, correlations between estimates of G.C.A. and inbred values were positive and only two of them were not significant (table 8). All these correlations but one ( 0.78 for plot yield) were not very high.

\section{DISCUSSION}

G.C.A. effects appeared to be mainly responsible for the variability of the following characters: flowering earliness, lodging, leaf canopy, seed yield per plot, leaf number at rosette stage, yield components. If G.C.A. effects from the statistical subdivision of individual values supply most of additive variance for these above characters, this last variance overcomes dominance and epistasis variances in the considered population.

For height at rosette stage and at the beginning of flowering, for density at maturity, specific effects displayed the same or greater variance than general effects; thus dominance and epistasis are certainly more involved in the variability of these characters than in the variability of the first ones.

Variations of stem base diameter and of BII yield were not well explained by the parameters involved in the models (G.C.A., S.C.A., M.R.E., S.R.E.). These two characters are dependent on competition and consequently variable ; therefore a sample made of 4 plants (remote from each other) from the same plot is not sufficient. It would be better to sample a whole part of the plot so as to increase plant number and to take in account intravarietal competition which is involved in the total value for the plot.

Although traits measured on individuals are the most variable, any conclusion about these characters must be drawn with great caution because of bad sampling. Hybrid vigour which was measured on the same samples did not differ from 0 in as far as yield components were concerned, but did differ significantly if plot yield was considered (Buson, 1979). This is further evidence of a bad sampling.

There are reciprocal effects for height at the beginning of flowering, for flowering earliness, for leaf canopy and for density at maturity. For height and density, variances of these effects were greater of equal to S.C.A. variances, but for other characters this variance is lower than that of G.C.A.

Occurrence of reciprocal effects for several characters gives evidence of the role of nucleocytoplasmic interactions; however, for most of the important agronomic characters (yield, flowering earliness, lodging, leaf canopy), variance of reciprocal effects relative to variance of G.C.A. is very low, and thus reciprocal effects may at first be ignored in a breeding scheme.

As earlier reported for several species, variability of many agronomic characters in rape was found to be mainly due to G.C.A. effects. The knowledge of parental G.C.A. values would make possible the prediction of hybrid values before crossing.

Yield of maize (MOLL \& RoBINSON, 1967), of some forage crops (BREESE \& HAYWARD, 1972), of alfalfa (GALLAIS, 1977), of sorghum (LODHI et al., 1979), and of mustard (KATIYAR et al., 1976 and ASTHANA PANDEY, 1977) displays an additive variance greater than the non-additive one. Besides, the S.C.A. variance of height in wheat (RANDHAWA \& GILL, 1978) and in sorghum (LODHI et al., 1979) is greater than the G.C.A. variance, whereas it remains low in maize (ROBINSON et al., 1955) and in mustard (KATIYAR et al., 1976).

Further, in several of these species, there is a simultaneous occurrence of great additive variance and inbreeding 
TABLE 7

Correlation estimates between the G.C.A. effects of parents for different characters.

Correlations entre valeurs en A.G.C. des géniteurs pour divers caractères.

\begin{tabular}{|c|c|c|c|c|c|c|c|c|c|c|c|}
\hline & \multirow[b]{2}{*}{$\begin{array}{c}\text { Date of } \\
\text { flowering }\end{array}$} & \multicolumn{3}{|c|}{ Plot } & \multicolumn{5}{|c|}{ Individual plants } & \multirow[b]{2}{*}{$\begin{array}{c}1000 \text { seeds } \\
\text { weight } \\
\text { for BII }\end{array}$} & \multirow[b]{2}{*}{$\begin{array}{l}\text { Yield } \\
\text { on BI }\end{array}$} \\
\hline & & $\begin{array}{l}\text { Leaf } \\
\text { canopy }\end{array}$ & $\begin{array}{l}\text { Lodging } \\
\text { susceptib. }\end{array}$ & $\begin{array}{l}\text { Seed } \\
\text { yield }\end{array}$ & $\begin{array}{l}\text { Pod nbr } \\
\text { on BI }\end{array}$ & $\begin{array}{l}\text { Pod nbr } \\
\text { on BII }\end{array}$ & $\begin{array}{l}\text { Seed nbr } \\
\text { per pod } \\
\text { for BI }\end{array}$ & $\begin{array}{l}\text { Seed nbr } \\
\text { per pod } \\
\text { for BII }\end{array}$ & $\begin{array}{c}1000 \text { seeds } \\
\text { weight } \\
\text { for BI }\end{array}$ & & \\
\hline \multirow{4}{*}{ Plot } & $\begin{array}{c}\text { Date of } \\
\text { flowering }\end{array}$ & 0,153 & $-0,340 *$ & $-0,024$ & $-0,048$ & $-0,180$ & 0,164 & $-0,180$ & $0,503 * *$ & 0,303 & 0,373 \\
\hline & $\begin{array}{l}\text { Leaf } \\
\text { canopy }\end{array}$ & & $-0,465^{* *}$ & $0,793 * *$ & $-0,319$ & $-0,253$ & $0,380 *$ & $-0,070$ & $-0,040$ & 0,052 & 0,104 \\
\hline & $\begin{array}{c}\text { Lodging } \\
\text { susceptibility }\end{array}$ & & & $-0,460 * *$ & $-0,176$ & 0,230 & $-0,209$ & 0,287 & $-0,382 *$ & $-0,176$ & $-0,484 *$ \\
\hline & Seed yield & & & & $-0,133$ & 0,022 & $0,561 * *$ & 0,166 & $-0,165$ & $-0,044$ & 0,302 \\
\hline \multirow{6}{*}{$\begin{array}{l}\text { Individual } \\
\text { plants }\end{array}$} & $\begin{array}{c}\text { Pod nbr } \\
\text { on BI }\end{array}$ & & & & & 0,320 & $-0,181$ & 0,205 & $0,395 *$ & 0,040 & $0,612 *$ \\
\hline & $\begin{array}{c}\text { Pod nbr } \\
\text { on BII }\end{array}$ & & & & & & $-0,101$ & $0,535 *$ & $-0,050$ & 0,040 & $-0,064$ \\
\hline & $\begin{array}{l}\text { Seed nbr per } \\
\text { pod for BI }\end{array}$ & & & & & & & 0,273 & $0,362 *$ & 0,196 & $0,548^{* *}$ \\
\hline & $\begin{array}{l}\text { Seed nbr per } \\
\text { pod for BII }\end{array}$ & & & & & & & & $-0,306$ & $-0,095$ & 0,135 \\
\hline & $\begin{array}{l}1000 \text { seed } \\
\text { weight for } B I\end{array}$ & & & & & & & & & $-0,206$ & 0,316 \\
\hline & $\begin{array}{c}1000 \text { seed } \\
\text { weight for } \mathrm{BII}\end{array}$ & & & & & & & & & & 0,202 \\
\hline
\end{tabular}

* Significant at $5 \%$ limit.

** Significant at $1 \%$ limit.

* Significatif avec un risque de 5 p. 100.

** Significatif avec un risque de 1 p. 100.

TABLE 8

Correlation estimates between inbred values and G.C.A. estimates for several characters. Corrélations entre les valeurs en lignée et les valeurs en A.G.C. pour quelques caractères.

\begin{tabular}{llcc}
\hline \hline \multicolumn{1}{c}{ Individual plants } & & Plot \\
\hline \multicolumn{1}{c}{ Character } & $\begin{array}{c}\text { Estimate of } \\
\text { correlation } \hat{\rho}\end{array}$ & Character & $\begin{array}{c}\text { Estimate of } \\
\text { correlation } \hat{\rho}\end{array}$ \\
\hline Pod number on BI & $0,579 * *$ & $0,540^{* *}$ \\
Pod number on BII & 0,305 & Date of flowering & Leaf canopy \\
Seed number per pod on BI & $0,668^{* *}$ & Lodging & $0,516^{* *}$ \\
Seed number per pod on BII & 0,296 & $0,711^{* *}$ \\
1000 seed weight on BI & $0,558^{* *}$ & Seed yield & $0,780^{* *}$ \\
1000 seed weight on BII & $0,401^{*}$ & & \\
Yield of BI & $0,702^{* *}$ & & \\
\hline
\end{tabular}

* Significant at $5 \%$.

** Significant at $1 \%$.

* Significatif avec un risque de 5 p. 100.

** Significatif avec un risque de 1 p. 100.

depression. This occurrence may be well explained if heterosis can be attributed to partial or total dominance effects and if favourable gene frequency is low. But, it is not well explained in the case of maize or alfalfa (GALLAIS, 1977) where heterosis is very high and cannot be attributed only to dominance effects, but also to overdominance effects; this is generally the case for allogamous plants.

The concepts of "internal balance" and "relation balance » as defined by LERNER in 1958 provide explanation of this coexistence. Heterozygotes would have good polyge- nic regulation due to good internal balance between allelic combinations within gene sequences and to good relation balance, demonstrating the heterozygous state of each locus. The biological reality of the internal balance is based on the linkat concept; interactions between homologous linkats fit with the relation balance (DEMARLY, 1977). DEMARLY (1972) was the first to introduce the concept of linkat and to define a cluster of loci along a chromosomal segment which has a favourable selective value and would pass from one generation to another. Natural selection 
would thus have created groups of coadapted genes where the recombination process would be slowed down. Epistasis between loci would have been slowly introduced in the linkats by natural selection. This would be particularly true with complex characters or characters with high selective value (GALlAIS, 1977).

The simultaneous occurrence of a great G.C.A. variability and a high heterosis in allogamous plants may be well explained, assuming that differences between parental G.C.A. values result from dominant genes grouped into acting linkats provided complementation between other genes is good (relation balance) (GALLAIS, 1976).

In contrast, neutral or elementary characters would not be organized into linkats; possibly these genes would be mostly scattered within the genome and a non-additive variance would be expressed (GALLAIS, 1977).

Besides, PANDEY (1972) has suggested that recombination is under a double control : i) a general control due to dominant genes which would increase crossing-over, ii) a more subtile control due to recessive genes which would locally increase crossing-over rate.

Thus, inbreeding in allogamous plants would cause negative effects :

i) the relation balance would not be at equilibrium; this would impair the expression of favourable genes or linkats ;

ii) lethal recessive plants would appear ;

iii) some recessive alleles would be expressed, thus increasing the crossing-over rate and consequently disrupting the linkats.

In the case of rape, as for several autogamous plants, the heterosis phenomenon is weaker than in many allogamous plants and we can assume that it is partly due to dominance effects ; anyway we must say that our results do not completely support this theory since about $50 \%$ of the hybrids outdo the best parent (BUSON, 1979).

However, this theory is in good agreement with the positive correlations between G.C.A. and inbred values found for most of the characters. All but the yield correlation $(\hat{\rho}=0.78)$ are not very high, but the constant positive value proves some genetic similitude of hybrids and inbreds. This supports earlier results (LEFORT-BUSON, 1982) providing evidence of the physiological identity of hybrid and inbred plants. Thus, in rape, the mean value of the inbred line could predict its mean value in cross for, at least, seed yield.

Moreover, the population under study is constituted of inbred lines and may be in a state of linkage disequilibrium that must increase the G.C.A. variance relatively to S.C.A. variance.

In rape there is a great number of hybrids outyielding the best parent and the variability of specific effects is greater than variability of general effects for height which has a low selective value, just as in alfalfa (GALLAIS, 1976); so we think that there may also be an organization into « linkats " in semi-autogamous plants. And, if so, linkats will not have the same meaning as in total allogamous plants, of course ; they may be better preserved than in allogamous plants. It is even possible that selection has resulted in the elimination of all lethal recessive genes as well as of genes causing local increase of crossing-over rate. Vigour would be maintained because of a great number of major genes and of epistasis effects between favourable linkats (DEMARLY, 1977). The origin of genetic variability would be then the same in inbred and hybrid plants belonging to partly cross-pollinated species. In these species, lack of a good relation balance which is required for the optimized expression of major genes might be the cause of a much lower heterosis, compared to heterosis in an allogamous species.

\section{CONCLUSIONS}

Results of a single year and single location experiment performed in winter rape (Brassica napus $L$.) emphasize the fact that the variability of yield, of its components and of several agronomic characters (except height and plant density) are mainly due to additive variance. A second experiment performed on an other sample from the same population confirms these early results, and breeding of $F_{1}$ hybrid varieties could be based on the G.C.A. values of inbred lines composing that population. Furthermore, the use of correlations between characters would enable the use of a selective index involving several agronomic characters.

Heterosis can also be exploited through « double " or «three-way " hybrids provided their variance is higher than that of the $F_{1}$ hybrids (SCHNELL, 1975). Therefore, these different types of varieties should be compared before making a final choice.

In rape as in many other allogamous species, high additivity variance coexists with heterosis ; but, this phenomenon seems less pronounced in rape. In an autogamous or semi-autogamous species with both self- and cross-pollinization, genetic variability is more likely to have the same origin in hybrids and inbred lines; heterosis would be partly due to an accumulation of major genes and vigour could therefore be fixed with time. In allogamous species, the genetic regulation of these characters would be different in hybrids compared to inbreds since a good relation balance would also be required for the expression of some major genes in heterozygotes. Therefore, heterosis (which is relatively higher in allogamous plants) might not soon be fixed in homozygotes as well as for autogamous plants, even if it appeared to do so (additivity in cross).

So, we would like to investigate first the relations between homozygote and heterozygote genetic mechanisms, and then the evolution of some genetic parameters in autogamous or semi-autogamous species with increasing inbreeding rate of population. These future studies would provide a better understanding of the differences between autogamous and allogamous plants and would be of practical significance for the breeding of both types of species.

Reçu le 3 juin 1981 Accepté le 20 novembre 1981

\section{ACKNOWLEDGMENTS}

The authors are very grateful to G. LEFORT for time spent in discussion on biometrical and biological approaches of this study.

\section{REFERENCES}

Asthana A. N., Pandey V. K., 1977. Combining ability and rank correlations in a diallel cross of indian mustard (Brassica juncea). Exp. Agric., 13 (1), 71-79.

Breese E. L., Hayward M. D., 1972. The genetic basis of present breeding methods in forage crops. Euphytica, 21, 324-336.
Buson M., 1979. Heterosis et paramètres génétiques de quelques caractères agronomiques chez le colza oléagineux (Brassica napus L.). Thèse de $3^{\mathrm{c}}$ cycle, Paris VI, $78 \mathrm{p}$.

Clarke J. M., 1977. Growth relationships and yield of Brassica napus. Thesis Saaskatoon, Saskatchewan, $158 \mathrm{p}$. 
Clarke J. M., 1978. Effects of leaf removal on yield and yield components of Brassica napus. Can. J. Plant Sci., 58 (4), 1103-1105.

Demarly Y., 1972. Commentaires sur les aptitudes à la combinaison. Ann. Amélior. Plant., 22 (2), 187-200.

Demarly Y., 1977. Génétique et amélioration des plantes. Masson, Paris, $287 \mathrm{p}$.

Gallais A., 1976. Sur la signification de l'aptitude générale à la combinaison. Ann. Amélior. Plant., 26 (1), 1-14.

Gallais A., 1977. Contribution à l'étude théorique et expérimentale de l'hétérosis chez une plante allogame autotétraplöde. Thèse de Doctorat d'état, Paris XI, 306 p.

Katiyar R. P., Mishra B., Singh S. N., Chauhan Y. S., 1976. Genetic variability, heritability and genetic advance of yield and its components in indian mustard. Ind. J. agric. Sci., 44 (5), 291-293. Lefort G., 1977. Remarques sur la modélisation et l'interprétation des dispositifs diallèles. Ann. Amélior. Plant., 27 (2), 171-202.

Lefort-Buson M., 1982. Genetic study of some agronomic characters in winter oilseed rape (Brassica napus L.) I. Heterosis. Agronomie, 2 (4), 315-322.
Lerner I. M., 1958. The genetic basis of selection. John Wiley and sons, New York, $298 \mathrm{p}$.

Lodhi G. P., Dangi O. P., Het Ram, 1979. Heterosis and combining ability for forage yield and its components in sorghum. Genet. agrar., 33, 15-24.

Moll E. H., Robinson H. F., 1967. Quantitative genetic investigation of yield of maize. Züchter, 57, 192-199.

Pandey K. K., 1972. Origin of genetic variation : regulation of genetic recombination in the higher organisms. A theory. Theor. appl. Genet., 42, 250-260.

Randhawa A. S., Gill K. S., 1978. Genetic variability and interelationships under different mating systems of wheat. Genet. agrar., 32, 287-297.

Robinson H. F., Comstock R. E., Harvey P. H., 1955. Genetic variances in open-pollinated varieties of corn. Genetics, 40, 45-60.

Schnell F. W., 1975. Type of variety and average performance in hybrid maize. Z. Pflanzenzücht., 74, 177-188. 